\title{
The Effects of Financial Education on Financial Literacy in Italy
}

\author{
Gian Paolo Stella ${ }^{1}$, Umberto Filotto $^{1}$, Enrico Maria Cervellati $^{2}$, Elvira Anna Graziano ${ }^{3}$ \\ ${ }^{1}$ Department of Management and Law - University of Rome "Tor Vergata" Via Columbia, 20, 0133 Rome, Italy \\ ${ }^{2}$ Department of Management - Ca' Foscari University of Venice, Fondamenta San Giobbe 873 Cannaregio, 30121 \\ Venice, Italy, \\ ${ }^{3}$ Link Campus University, Via del Casale di S. Pio V, 00165, Rome, Italy \\ Correspondence: Gian Paolo Stella, Department of Management and Law - University of Rome "Tor Vergata" Via \\ Columbia, 20, 0133 Rome, Italy.
}

Received: January 29, 2020

Accepted: March 13, $2020 \quad$ Online Published: March 20, 2020

doi:10.5539/ibr.v13n4p44

URL: https://doi.org/10.5539/ibr.v13n4p44

\begin{abstract}
This study assesses whether participation in financial education programmes has a positive effect on financial literacy. To pursue this goal, we conducted an online survey in March 2019. The sample comprised 918 Italian adults aged 30 to 91 . We asked respondents if they had participated in financial education programmes during school or university years. The results show the effectiveness of participating in financial education programmes, as the rate of correct responses to financial literacy questions was higher for those who had completed one of the above-mentioned programmes than for those who did not. In addition, those who participated in a financial literacy programme during university years gave more correct answers compared to those who participated in one of these programmes during school (non-university) years.
\end{abstract}

Keywords: financial education, financial literacy, structural equation model, Italy

JEL codes: A20, D12, D14, I20.

\section{Introduction}

During their lives, people are called upon to make decisions that have positive or negative effects on their wellbeing. Financial choices play a particularly important role in individuals' lives, and it is important to have the knowledge and skills to behave in a way that is more appropriate for one's own needs and that protects one's own economic wellbeing (Greenspan, 2005).

Financial literacy literature studies people's knowledge, attitudes and skills related to finance. The Organisation for Economic Co-operation and Development (OECD) defines financial literacy as "the knowledge and understanding of financial concepts and risks, as well as the skills, motivation and confidence to apply such knowledge and understanding in order to make effective decisions in a range of financial contexts, improve the financial well-being of individuals and society and enable participation in economic life" (OECD, 2014, p. 19).

Previous studies indicated that more financially literate individuals are skilled in savings management, pension planning and wealth accumulation (Ameriks, Caplin, \& Leahy, 2003; Hilgert, Hogarth, \& Beverly, 2003; Lusardi \& Mitchell, 2007, 2011; Bucher-Koenen \& Lusardi, 2011; Delavande, Rohwedder, \& Willis, 2008; Stango \& Zinman, 2009; Hung, Parker, \& Yoong, 2009; van Rooij, Lusardi, \& Alessie, 2012; Lusardi \& Tufano, 2015; Algood \& Walstad, 2015; Jappelli \& Padula, 2015; Hastings \& Mitchell, 2020).

For these reasons, financial education programmes are "the process in which users of financial services improve their understanding of financial products, notions and risks, and on the basis of information, instructions and advice develop skills and confidence in making financial decisions capable of improving their wealth" (OECD, 2005, p.31).

This topic is of great interest in Italy in particular, as a study by Standard \& Poor's found that the average rate of financial literacy was $37 \%$ in the country while the EU average was $52 \%$ (Klapper, Lusardi, \& Van Oudheusden, 2015). ${ }^{1}$ However, if on the one hand financial literacy is positively related to financial behaviour - understood

\footnotetext{
${ }^{1}$ The rate was calculated as participants' percentage of correct answers to financial literacy questions.
} 
as the capacity of individuals to manage investments and accumulate savings (Lusardi, 2004; Hilgert et al., 2003; Lyons, 2007; Bell, Gorin, \& Hogarth, 2009) - on the other hand relevant literature also examines the positive effects of financial education programmes on people's literacy and subsequent choices (Lyons, Palmer, Jayaratne, \& Scherpf, 2006; Alsemgeest, 2015).

The present work aims to assess whether participation in financial education programmes ${ }^{2}$ during school or university years has a positive effect on financial literacy levels. We distributed an online survey containing financial literacy questions, questions regarding the participation in educational programmes, as well as socio-economic information.

We conducted our study in March 2019 with a sample of 918 adults living in Italy. The results indicate that participation in financial education programmes during school or university periods has a positive effect on financial literacy. Furthermore, participation in financial education programmes during university years has a greater effect than participation during school years.

This study is divided into the following sections. In section 1, we present the literature review; in section 2, we outline the research hypotheses and measures; in section 3, we describe the sample, the variables used and the descriptive analyses; in section 4, we present the results; and in section 5, we outline the conclusions.

\section{Literature Review}

As mentioned above, the literature analysing the impact of financial education programmes on financial literacy is divided between those authors who advocate their effectiveness and those who do not.

Among the latter group of studies, Mandell and Klein (2009) study of high school students in the US analysed the effects of participating in a finance course and found no significant differences between those who attended and those who did not. According to Campbell (2006), improvements in financial literacy can result less from participation in financial education programmes than from exogenous factors ignored in econometric regressions. Fernandes, Lynch, and Netemeyer, (2014) analysed 90 studies on an international scale and found that completion of financial education programmes did not produce a significant change in the participants' long-term behaviour. Hung et al., (2009) and Hastings, Madrian, and Skimmyhorn, (2013) have observed similar results in their own studies. Additionally, Carpena, Cole, Shapiro, and Zia, (2011) study of 1,200 households in India revealed that financial education programmes had little effect on people's ability to make financial calculations and analyse insurance costs. However, the same study found that participation in such programmes led to improvements in financial product management, selection and planning skills. Willis (2008) explored the inability of financial education programmes to provide the right mix of knowledge and skills. The author demonstrated that financial education interventions cannot improve individuals' financial behaviour to prevent them from making the wrong financial choices. Additionally, Willis (2011) argues that such initiatives would not be successful in the adult population and highlights that only stricter regulations can induce more conscious financial behaviour.

With regard instead to the first group of studies, Bernheim, Garrett, and Maki, (2001) analysed a sample of individuals aged 30 to 49 who had completed a financial education course during high school and found that these programmes led people to accumulate more wealth and savings in the long term. Studies of the benefits of financial education programmes have found that those who completed such programmes have positively changed their spending and saving habits (Danes, Huddleston-Casas, \& Boyce, 1999; Danes \& Haberman, 2004). According to Lusardi (2008), financial education programmes have positive effects on families' ability to make savings and investment decisions. Carlin et al.'s (2012) study of 2,357 students in the US aged 13 to 19 found that financial education increased students' ability to create a budget consistent with their income and expenditures. According to Lührmann, Serra-Garcia, and Winter, (2015), financial education programmes improve adolescents' purchasing behaviour by making them more cautious and less impulsive. Among the measures that need to be developed for the success of financial education programmes, special mention should be made of teachers' ability to easily explain financial concepts and the prudence of measuring ex ante participants' financial literacy levels to verify the effectiveness of education programmes (Walstad, Rebeck, \& MacDonald, 2010). Lusardi and Mitchell (2014) connected the success of a financial education programme to the organisers' ability to transmit financial concepts into a language the target audience could understand.

\section{Research Hypotheses}

The hypotheses examined in the study are the following.

\footnotetext{
${ }^{2}$ School years are defined as the period of education from 10 to 18 years of age, while university years are defined as the period of education between 19 and 26 years of age.
} 
$\mathrm{H}_{0}$ : Participation in financial education programmes does not affect financial literacy in adulthood.

$\mathrm{H}_{1}$ : Participation in financial education programmes during school years positively affects financial literacy in adulthood.

$\mathrm{H}_{2}$ : Participation in financial education programmes during university years positively affects financial literacy in adulthood.

$\mathrm{H}_{3}$ : Participation in financial education programmes during university years has a greater positive influence than participation during school years.

\subsection{Measures}

The variables analysed in this study concern participation in financial education programmes. In particular, we examined two variables. The first was whether respondents had attended financial education programmes during (primary and secondary) school years, while the second was whether or not respondents had participated in financial education programmes during university years both variables were binary (dummies) where 1 indicated attendance while 0 indicated lack of attendance. Following the guidelines provided by the OECD (2014), we quantified financial literacy levels by analysing three different factors: knowledge, skills and financial attitudes.

As far as knowledge is concerned, five questions from report conducted by the National Financial Capability Studies $(\mathrm{NFCS})^{3}$ were included in the survey. Lusardi and Mitchell formulated these questions as a key benchmark for measuring levels of financial knowledge (Lusardi \& Mitchell, 2014).

Regards financial skills, we used Stella, Filotto, \& Cervellati, (2020) questions. The questions analysing financial skills tested respondents' ability to make the best decision in five different scenarios. Each question about financial knowledge and ability had only one correct option. Correct answers were worth one point while incorrect answers were worth zero. When analysing the results, we recorded the "do not know" and "refuse to answer" options as incorrect, in line with the OECD methodology.

Finally, with regard to financial attitudes, we examined Stella et al.,(2020) questions. Respondents could indicate their preference on a Likert scale ranging from 1 ("completely disagree") to 7 ("completely agree"). The aim was to assess respondents' attitudes towards financial issues, such as savings and investments.

In Table 1, we summarise the questions used in this study, which define scenarios to measure financial literacy, as well as the socio-economic variables such as gender, age, education, work status and income that were included in the survey.

Table 1. Variable description

\begin{tabular}{|c|c|}
\hline Variable & Description \\
\hline Financial education - school years & Participation in programme during school years: $1=$ Yes, $0=$ No \\
\hline Financial education - university years & Participation in programme during university years: $1=$ Yes, $0=$ No \\
\hline Financial skills & Overall score on financial skills questions; range 1-5 \\
\hline Financial knowledge & Overall score on financial knowledge questions; range 1-5 \\
\hline Financial attitude & Overall score on financial attitude questions; range 1-7 \\
\hline Gender & $1=$ male, $0=$ female \\
\hline Age & Age in March 2019 \\
\hline Marital status & $1=$ married, $2=$ divorced, $3=$ widowed, $99=$ refuse to answer \\
\hline Education & $\begin{array}{l}1=\text { primary school certificate, } 2=\text { secondary school certificate, } 3=\text { high school } \\
\text { diploma, } 4=\text { bachelor's degree, } 5=\text { master's degree, } 6=\text { specialization } \\
\text { course } / \mathrm{PhD}, 7=\mathrm{I} \text { have not completed high school education, } 98=\text { other, } 99= \\
\text { refuse to answer }\end{array}$ \\
\hline Work status & $\begin{array}{l}1=\text { full-time work }(>35 \text { hours/week), } 2=\text { part-time work }(<35 \text { hours } / \text { week }), 3= \\
\text { stay at home, } 4=\text { student, } 5=\text { retired, } 6=\text { disabled or unable to work, } 7= \\
\text { unemployed, } 98=\text { other, } 99=\text { refuse to answer }\end{array}$ \\
\hline Income & $\begin{array}{l}1=\text { less than } \$ 10,000,2=\text { between } \$ 10,000 \text { and } \$ 20,000,3=\text { between } \$ 20,000 \text { and } \\
\$ 40,000,4=\text { between } \$ 40,000 \text { and } \$ 80,000,5=\text { more than } \$ 80,000,99=\text { refuse to } \\
\text { answer }\end{array}$ \\
\hline
\end{tabular}

\footnotetext{
${ }^{3}$ http://www.usfinancialcapability.org/downloads/NFCS_2015_State_by_State_Qre.pdf
} 


\section{Results}

\subsection{Sample Description and Descriptive Analysis}

Respondents in our sample are Italian adults, aged 30 to 91 as of March 2019. The data were collected using the Computer-Assisted Web Interview (CAWI) survey methodology. According to Midler (2013), this method is based on the realisation of a research questionnaire disclosed on the website and all questions are previously predefined following the guidelines provided by Fowler et al. (1990). We have invited to participate in this research 1,400 individuals, randomly selected. At the end, we collected 1,000 questionnaires, and by excluding not considering the ones that lacked data for our analysis, we ended up with 918 questionnaires. In Table 2, we present descriptive statistics. ${ }^{4}$

Table 2. Descriptive statistics $(N=918)$

\begin{tabular}{|c|c|c|c|c|}
\hline Variable & Mean & $S D$ & Min & Max \\
\hline Financial education - school & .193 & .395 & 0 & 1 \\
\hline Financial education - university & .226 & .418 & 0 & 1 \\
\hline Financial skills & 3.198 & 1.285 & 0 & 5 \\
\hline Financial knowledge & 2.674 & 1.340 & 0 & 5 \\
\hline Financial attitude & 5.972 & .934 & 1 & 7 \\
\hline Gender & 1.516 & .500 & 0 & 1 \\
\hline Age & 50.785 & 12.196 & 30 & 91 \\
\hline Marital status & 1.748 & 7.217 & 1 & 99 \\
\hline Education & 4.639 & 9.430 & 1 & 99 \\
\hline Work status & 1.915 & 1.589 & 1 & 99 \\
\hline Income & 19.722 & 36.591 & 1 & 99 \\
\hline
\end{tabular}

\subsection{Preliminary Analysis}

In Table 3, we present financial literacy levels — broken down by knowledge, skills and attitudes — related to participation in financial education programmes during school and university years.

Table 3. Comparison between financial literacy and education

\begin{tabular}{|c|c|c|c|c|c|}
\hline & & \multicolumn{2}{|c|}{$\begin{array}{c}\text { Financial education - } \\
\text { School years (\%) }\end{array}$} & \multicolumn{2}{c|}{$\begin{array}{c}\text { Financial education - } \\
\text { university years (\%) }\end{array}$} \\
\hline Variable & Score & No & Yes & No & 1.9 \\
\hline Financial knowledge & 0 & 9.3 & 2.8 & 9.9 & 4.3 \\
\hline & 1 & 12.8 & 7.3 & 13.9 & 18.8 \\
\hline & 2 & 23.2 & 15.8 & 22.7 & 26 \\
\hline & 3 & 28.2 & 23.7 & 27.7 & 37.5 \\
\hline & 4 & 22.0 & 38.4 & 21.5 & 11.5 \\
\hline & 5 & 4.5 & 11.9 & 4.2 & 0.5 \\
\hline & 0 & 4.3 & 2.8 & 5.1 & 5.8 \\
\hline & 1 & 6.7 & 8.5 & 7.5 & 10.6 \\
\hline & 2 & 15.1 & 13.0 & 15.9 & 24.5 \\
\hline & 3 & 29.1 & 22.6 & 28.9 & 36.1 \\
\hline & 4 & 32 & 31.1 & 30.6 & 2.6 \\
\hline
\end{tabular}

The results indicate that participation in financial education programmes positively affects financial knowledge, skills and attitudes. Respondents who attended programmes during school years scored higher on financial knowledge and skills questions. These participants also displayed more conscious and prudent financial attitudes. The results improved significantly for those who participated in a financial programme during university compared to those who did so only during school. In Table 4, we present the correlations between our variables.

${ }^{4}$ For the variables of marital status, level of education, work status and income, the answers "do not know" and "refuse to answer", coded respectively as 98 and 99 , were omitted from the analysis to avoid abnormal fluctuations in the values of the average and, consequently, of the standard deviation. 
Table 4. Correlation matrix

\begin{tabular}{|l|c|c|c|c|c|}
\hline Variables & $\mathbf{1}$ & $\mathbf{2}$ & $\mathbf{3}$ & $\mathbf{4}$ & $\mathbf{5}$ \\
\hline Financial education - Schools & 1 & & & & \\
\hline Financial education - University & $.555^{* * *}$ & 1 & & & \\
\hline Financial skills & $.159^{* * *}$ & $.043^{*}$ & 1 & & \\
\hline Financial knowledge & $.242^{* * *}$ & $.173^{* * *}$ & $.407 * * *$ & 1 & \\
\hline Financial attitude & .031 & .026 & $.147^{* * *}$ & $.103^{* * *}$ & 1 \\
\hline
\end{tabular}

Note: Asterisks indicate the significance of the coefficients at $10 \%(*), 5 \%(* *)$ and $1 \%(* * *)$.

Participation in a financial education programme during school years was positively related to financial skills and knowledge, but not to attitude. On the other hand, the other variables had positive and significant correlations.

\subsection{Financial Education Structural Equation Model}

In Figure 1, we present the structural model used to test the assumptions underlying this research.

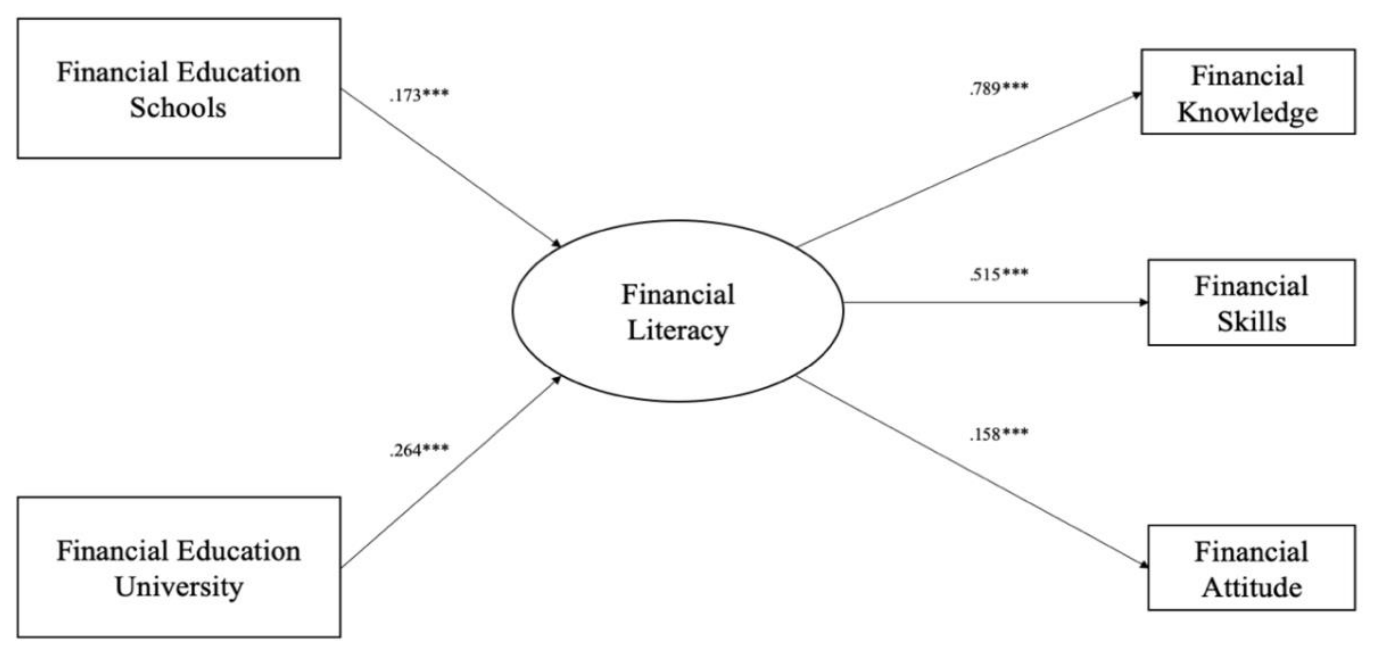

Figure 1. Model of structural equations

The results indicate that the measurement model fits well with the data collected from the sample. The results suggest rejecting the null hypotheses $\left(\mathrm{H}_{0}\right)$, i.e., that participation in financial education programmes does not affect financial literacy in adulthood. In particular, both the comparative fit index (CFI) and the Tucker-Lewis index $(\mathrm{TLI})$ were greater than $.9(\mathrm{CFI}=.958$; TLI $=.917)$, indicating strong data adaptation $($ Bentler, 1990). The chi-square value was significant $(\chi$-square $[12]=283.129, p<.001 * * *)$, and the root-mean square error of approximation (RMSEA) was equal to .045 , confirming a close adaptation of the model to the data.

The results suggest not rejecting the first hypothesis $\left(\mathrm{H}_{1}\right)$, i.e., that participation in financial education programmes during school years positively affects financial literacy in adulthood. We thus detect a positive influence of financial education programmes during school years on adults' financial literacy $\left(\mathrm{H}_{1}\right.$ : Standardised Path Coefficient $[\mathrm{SPC}]=.173, p<.001 * * *)$.

The results also suggest not rejecting the second hypothesis $\left(\mathrm{H}_{2}\right)$, i.e., that participation in financial education programmes during university years positively affects financial literacy in adulthood. Thus, it seems to confirm the positive effects of programmes completed during university on financial literacy $\left(\mathrm{H}_{2}: \mathrm{SPC}=.264, p\right.$ $<.001 * * *$ ). These results appear in line with previous studies (e.g., Lusardi, 2004; Hilgert et al., 2003) showing that participation in financial education programmes translated into an improvement in adults' financial literacy and, in turn, into a better financial decision-making capacity.

With regard to our third hypothesis $\left(\mathrm{H}_{3}\right)$, i.e., that participation in financial education programmes during university years has a greater positive influence than participation during school years, our results seem to suggest not rejecting it. This finding confirms the third hypothesis of the study. 


\section{Conclusions}

The aim of the present study was to verify whether participation in a financial education programme during school or university years had a positive effect on the financial literacy of a sample of adults living in Italy. The results suggest that participation in financial education programmes during both school and university has a positive effect on adults' financial literacy. A comparison of participation during different time periods revealed that receiving financial education during university years had a greater positive effect on financial literacy than receiving it during school. The results support Bernheim et al., (2001) conclusion that financial education is essential for increasing financial literacy and the quality of people's financial decision-making.

This study contributes to the existing literature by providing evidence of how financial literacy initiatives can improve levels of understanding in Italy and is especially in line with the results obtained by the countries, specifically especially in northern Europe, present in the European Union.

However, the analyses conducted in this work indicate that participation in financial education programmes has been very low among Italian adults. Thus, the findings highlight the need for closer collaboration between public and private authorities to agree on the methods and timing of long-term financial education programmes in Italy.

\section{References}

Allgood, S., \& Walstad, W. B. (2016). The effects of perceived and actual financial literacy on financial behaviors. Economic inquiry, 54(1), 675-697. https://doi.org/10.1111/ecin.12255

Alsemgeest, L. (2015). Arguments for and against financial literacy education: where to go from here? International Journal of Consumer Studies, 39(2), 155-161. https://doi.org/10.1111/ijcs.12163

Ameriks, J., Caplin, A., \& Leahy, J. (2003). Wealth accumulation and the propensity to plan. The Quarterly Journal of Economics, 118(3), 1007-1047. https://doi.org/10.1162/00335530360698487

Bell, C. J., Gorin, D. R., \& Hogarth, J. M. (2009). Does Financial Education Affect Soldiers' Financial Behavior? Networks Financial Institute Working Paper. https://doi.org/10.2139/ssrn.1445635

Bentler, P. M. (1990). Comparative fit indexes in structural models. Psychological bulletin, 107(2), 238. https://doi.org/10.1037/0033-2909.107.2.238

Bernheim, B. D., Garrett, D. M., \& Maki, D. M. (2001). Education and saving:: The long-term effects of high school financial curriculum mandates. Journal of public Economics, 80(3), 435-465. https://doi.org/10.1016/s0047-2727(00)00120-1

Bucher-Koenen, T., \& Lusardi, A. (2011). Financial literacy and retirement planning in Germany. Journal of Pension Economics and Finance, 10(4), 565-584. https://doi.org/10.1017/s1474747211000485

Campbell, J. Y. (2006). Household finance. The journal of finance, 61(4), 1553-1604. https://doi.org/10.1111/j.1540-6261.2006.00883.x

Carlin, B. I., \& Robinson, D. T. (2012). Financial education and timely decision support: Lessons from Junior Achievement. American Economic Review, 102(3), 305-08. https://doi.org/10.1257/aer.102.3.305

Carpena, F., Cole, S., Shapiro, J., \& Zia, B. (2011). Unpacking the causal chain of financial literacy. The World Bank. https://doi.org/10.1596/1813-9450-5798

Danes, S. M., \& Haberman, H. (2004). Evaluation of the NEFE high school financial planning program 2003-2004. Denver, CO: National Endowment for Financial Education

Danes, S. M., Huddleston-Casas, C., \& Boyce, L. (1999). Financial planning curriculum for teens: Impact evaluation. Journal of Financial Counseling and Planning, 10(1), 26.

Delavande, A., Rohwedder, S., \& Willis, R. J. (2008). Preparation for retirement, financial literacy and cognitive resources. Michigan Retirement Research Center Research Paper, (2008-190). https://doi.org/10.2139/ssrn.1337655

Fernandes, D., Lynch Jr, J. G., \& Netemeyer, R. G. (2014). Financial literacy, financial education, and downstream financial behaviors. Management Science, 60(8), 1861-1883. https://doi.org/10.1287/mnsc.2013.1849

Greenspan, A. (2005). The importance of financial education today. Social Education, 69(2), 64-66. Retrieved from https://www.bis.org/review/r011029a.pdf

Hastings, J. S., Madrian, B. C., \& Skimmyhorn, W. L. (2013). Financial literacy, financial education, and economic outcomes. Annu. Rev. Econ., 5(1), 347-373. 
https://doi.org/10.1146/annurev-economics-082312-125807

Hastings, J., \& Mitchell, O. S. (2020). How financial literacy and impatience shape retirement wealth and investment behaviors. Journal of Pension Economics \& Finance, 19(1), 1-20. https://doi.org/10.1017/s1474747218000227

Hilgert, M. A., Hogarth, J. M., \& Beverly, S. G. (2003). Household financial management: The connection between knowledge and behavior. Fed. Res. Bull., 89, 309. Retrieved from https://www.federalreserve.gov/pubs/bulletin/2003/0703lead.pdf

Hung, A., Parker, A., \& Yoong, J. (2009). Defining and Measuring Financial Literacy (No. WR-708). RAND Corporation. https://doi.org/10.2139/ssrn.1498674

Jappelli, T., \& Padula, M. (2015). Investment in financial literacy, social security, and portfolio choice. Journal of Pension Economics \& Finance, 14(4), 369-411. https://doi.org/10.1017/s1474747214000377

Klapper, L., Lusardi, A., \& Van Oudheusden, P. (2015). Financial Literacy Around the World: Insights from the $S \& P$ global finlit survey. World Bank Development Research Group, 1-27. Retrieved from http://nzz-files-prod.s3-website-eu-west-1.amazonaws.com/files/1/8/1/2015-Finlit_paper_17_F3_SINGLES _1.18658181.pdf

Lührmann, M., Serra-Garcia, M., \& Winter, J. (2015). Teaching teenagers in finance: does it work? Journal of Banking \& Finance, 54, 160-174. https://doi.org/10.1016/j.jbankfin.2014.11.009

Lusardi, A. (2004). Saving and the effectiveness of financial education. Pension Research Council WP2003-14. https://doi.org/10.2139/ssrn.476022

Lusardi, A. (2008). Household saving behavior: The role of financial literacy, information, and financial education programs (No. w13824). National Bureau of Economic Research. https://doi.org/10.3386/w13824

Lusardi, A., \& Mitchell, O. S. (2011). Financial literacy and planning: Implications for retirement wellbeing (No. w17078). National Bureau of Economic Research. https://doi.org/10.3386/w17078

Lusardi, A., \& Mitchell, O. S. (2014). The economic importance of financial literacy: Theory and evidence. Journal of economic literature, 52(1), 5-44. https://doi.org/10.1257/jel.52.1.5

Lusardi, A., \& Mitchelli, O. S. (2007). Financial literacy and retirement preparedness: Evidence and implications for financial education. Business economics, 42(1), 35-44. https://doi.org/10.2145/20070104

Lusardi, A., \& Tufano, P. (2015). Debt literacy, financial experiences, and overindebtedness. Journal of Pension Economics \& Finance, 14(4), 332-368. https://doi.org/10.1017/s1474747215000232

Lyons, A. C. (2007). Credit practices and financial education needs of Midwest college students. Networks Financial Institute Working Paper, (2007-WP), 23. https://doi.org/10.2139/ssrn.1060801

Lyons, A. C., Palmer, L., Jayaratne, K. S., \& Scherpf, E. (2006). Are we making the grade? A national overview of financial education and program evaluation. Journal of Consumer Affairs, 40(2), 208-235. https://doi.org/10.1111/j.1745-6606.2006.00056.x

Mandell, L., \& Klein, L. S. (2009). The impact of financial literacy education on subsequent financial behavior. Journal of Financial Counseling and Planning, 20(1). Retrieved from https://files.eric.ed.gov/fulltext/EJ859556.pdf

OECD (2014). PISA 2012 Results: Students and Money (Volume VI): Financial Literacy Skills for the 21st Century. PISA. OECD Publishing. Retrieved from http://www.oecd.org/pisa/keyfindings/PISA-2012-results-volume-vi.pdf

OECD. (2005). Improving Financial Literacy: Analysis of Issues and Policies. Retrieved from http://www.oecd.org/document/28/0,3343,en_2649_15251491_35802524_1_1_1_1,00.html

Stango, V., \& Zinman, J. (2009). What do consumers really pay on their checking and credit card accounts? Explicit, implicit, and avoidable costs. American Economic Review, 99(2), 424-429. https://doi.org/10.1257/aer.99.2.424

Stella, G. P., Filotto, U., \& Cervellati, E. M. (2020). A proposal for a new financial literacy questionnaire. International Journal of Business and Management, 15(2). https://doi.org/10.5539/ijbm.v15n2p34

Van Rooij, M. C., Lusardi, A., \& Alessie, R. J. (2012). Financial literacy, retirement planning and household wealth. The Economic Journal, 122(560), 449-47. https://doi.org/10.1111/j.1468-0297.2012.02501.x 
Walstad, W. B., Rebeck, K., \& MacDonald, R. A. (2010). The effects of financial education on the financial knowledge of high school students. Journal of Consumer Affairs, 44(2), 336-357. https://doi.org/10.1111/j.1745-6606.2010.01172.x

Willis, L. E. (2008). Against financial-literacy education. Iowa L. Rev., 94, 197.

Willis, L. E. (2011). The financial education fallacy. American Economic Review, 101(3), 429-34. https://doi.org/10.1257/aer.101.3.429

\section{Copyrights}

Copyright for this article is retained by the author(s), with first publication rights granted to the journal.

This is an open-access article distributed under the terms and conditions of the Creative Commons Attribution license (http://creativecommons.org/licenses/by/4.0/). 